\title{
All the Same The Words \\ Don't Go Away
}

Essays on Authors,

Heroes, Aesthetics, and

Stage Adaptations from

the Russian Tradition

Caryl

Emerson 


\begin{tabular}{r|l} 
STUDIES IN RUSSIAN AND SLAVIC & ARS ROSSIKA \\
LITERATURES, CULTURES AND HISTORY & \\
Series Editor: Lazar Fleishman & $\begin{array}{l}\text { Series Editor: David Bethea } \\
\text { (University of Wisconsin - Madison } \\
\text { and Oxford University) }\end{array}$
\end{tabular}

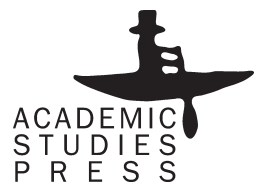



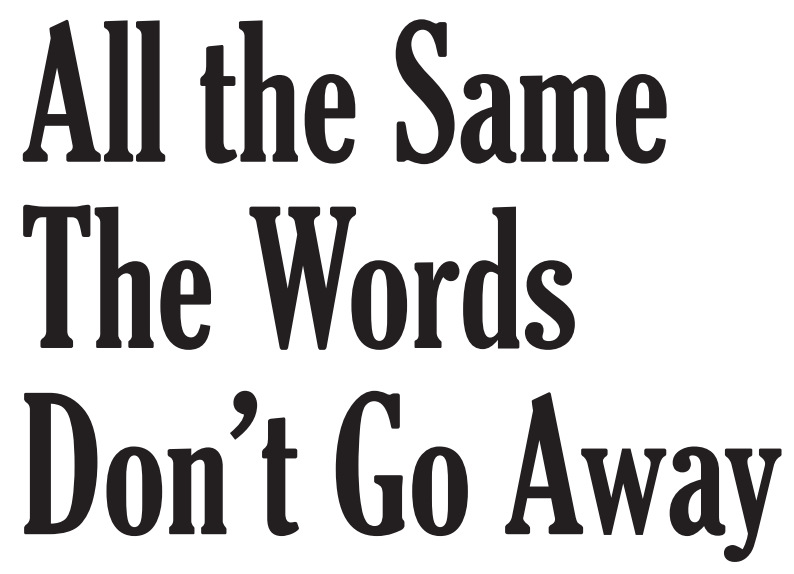

Essays on Authors,

Heroes, Aesthetics, and

Stage Adaptations from

the Russian Tradition

Caryl

Emerson 
Library of Congress Cataloging-in-Publication Data

Emerson, Caryl. All the same the words don't go away : essays on authors, heroes, aesthetics, and stage adaptations from the Russian tradition / Caryl Emerson.

p. cm. -- (Studies in Russian and Slavic literatures, cultures and history)

Includes bibliographical references and index.

ISBN 978-1-934843-81-9 (hardback)

1. Russian literature--History and criticism. 2. Russian

literature--Adaptations--History and criticism. I. Title.

PG2951.E46 2011

891.709--dc22

2010047494

Copyright $@ 2011$ Academic Studies Press

All rights reserved

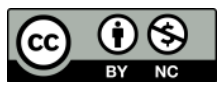

Effective May 23, 2016, this book will be subject to a CC-BY-NC license. To view a copy of this license, visit https://creativecommons.org/licenses/by-nc/4.0/. Other than as provided by these licenses, no part of this book may be reproduced, transmitted, or displayed by any electronic or mechanical means without permission from the publisher or as permitted by law.

ISBN 978-1-934843-81-9 (hardback)

ISBN 978-1-618111-28-9 (electronic)

Book design by Ivan Grave On the cover: Saskia Ozols Eubanks, St. Isaac's Cathedral After the Storm. Oil on Panel, 2010 (a fragment).

Published by Academic Studies Press in 2011

28 Montfern Avenue

Brighton, MA 02135, USA

press@academicstudiespress.com

www.academicstudiespress.com 
For Sophia

(Wisdom) 
